\title{
INTERFACES ENTRE A ANTROPOLOGIA E O DIREITO: UMA DISCUSSÃO SOBRE O ANTI ANTI-RELATIVISMO DE CLIFFORD GEERTZ
}

\author{
INTERFACES BETWEEN ANTHROPOLOGY AND LAW: A \\ DISCUSSION ON CLIFFORD GEERTZ'S ANTI ANTI-RELATIVISM
}

Luana Renostro Heinen ${ }^{1}$

Marcel Mangili Laurindo ${ }^{2}$

\begin{abstract}
RESUMO: A antropologia pode contribuir para que os juristas visualizem o fenômeno jurídico como produto da cultura e, por isso, marcado por grande diversidade. A proposta do trabalho é analisar como o relativismo e o anti anti-relativismo de Clifford Geertz podem lançar luzes sobre o direito. Apresenta-se o etnocentrismo e o evolucionismo cultural para depois explorar sua presença no direito e a contribuiçăo da antropologia, com o relativismo, para se questionar essas visōes. Em seguida, faz-se uma análise do anti anti-relativismo de Clifford Geertz para compreender as críticas que recebeu o relativismo e como Geertz as rebate, para se discutir, no segundo momento, como os juristas podem aprender a lançar um olhar através do espelho que possibilite criticar também os próprios pressupostos.
\end{abstract}

PALAVRAS-CHAVE: Relativismo. Anti anti-relativismo. Cultura. Direito.

\begin{abstract}
Anthropology can help jurists visualize the legal phenomenon as a product of culture, which is why great diversity marks it. The purpose of the paper is to analyze how Clifford Geertz's relativism and anti-relativism can shed light on the law. Ethnocentrism and cultural evolutionism are presented and then to explore their presence in law and the contribution of anthropology, with relativism, to question these visions. Then an analysis of the anti-relativism of Clifford Geertz is made to understand the criticisms received by relativism and how Geertz refutes them, to discuss, in the second moment, how jurists can learn to cast a glance through the mirror which makes it possible to criticize the assumptions themselves.
\end{abstract}

KEYWORDS: Relativism. Anti anti-relativism. Culture. Law.

1 Professora Adjunto da Universidade Federal de Santa Catarina (UFSC). Doutora em Direito pela UFSC. luana.heinen@ufsc.br

2 Defensor Público do Estado de Santa Catarina, Doutorando em Direito na Universidade Federal de Santa Catarina (UFSC) e Mestre em Sociologia Política pela UFSC. mangili84@gmail.com 


\section{INTRODUÇÃO: A INTERFACE ENTRE A ANTROPOLOGIA E O DIREITO}

Este trabalho parte da compreensăo da antropologia jurídica como compartimento particular do saber mais geral que é antropologia. A qualificaçăo jurídica situa-se, assim, no mesmo patamar que os outros adjetivos como cultural, econômica, política e social. ${ }^{3}$

Para autores como Rouland (2008) e Bôas Filho (2007), a antropologia jurídica se desenvolveu como uma espécie de subproduto do expansionismo imperial do século XIX: um saber voltado à dominaçâo - conhecer melhor as sociedades colonizadas tinha a finalidade de dominá-las de modo mais eficaz.

Prevaleceu, em seus primórdios, a dimensâo instrumental da antropologia, voltada à gestâo dos povos considerados "primitivos". Ao longo de seu desenvolvimento, entretanto, a antropologia foi se afastando progressivamente dessas características de origem - apresentou contradiçóes e ambiguidades que lhe permitiram superar as determinaçôes de seu contexto de formaçâo. Segundo Bôas Filho (2007, p. 339), ainda no período colonial, a antropologia também se caracterizou por posturas críticas da dominaçáo colonial.

Hoje, cabe questionar: quais as contribuiçōes que a antropologia pode trazer ao direito? Ou, ainda, como o olhar antropológico pode ajudar os juristas a visualizarem questôes que năo podem ser vistas a partir da "lente jurídica"?

Discutindo as implicaçōes e experiências da disciplina de antropologia jurídica nas Faculdades de Direito, Pazello, Maso e Kobora, concluem que o ensino de antropologia acaba por produzir perplexidades, na medida em que possibilita à comunidade acadêmica do direito visualizar que "seu objeto [de estudo] năo é universal nem tampouco o é sua forma de interpretá-lo e/ou realizá-lo" (2011, p. 86). Assim, a noçăo do direito como um campo cultural traz a ideia de um conhecimento articulado, contingente e ideográfico, contribuindo para a redefiniçáo de sua autoimagem, com vistas a problematizá-la no tempo e no espaço.

Visualizar o direito como campo cultural abre um novo universo de possibilidades para estudar ordenamento jurídico como um conjunto de regras em movimento, uma construçâo histórica e cultural que, portanto, pode ser produzida e reproduzida dentro e fora da esfera estatal.

É justamente essa a contribuiçâo da antropologia, vivenciada e problematizada por Pazello, Maso e Kobora, que Rouland exalta. Para o jurista francês, a teoria do Direito construída por Hans Kelsen, que acabara por identificar Estado e Direito e rejeitara o sincretismo metodológico e científico na construçăo da ciência jurídica, "deixou uma marca profunda nos juristas" (ROULAND, 2008, p. 403). Entretanto, apesar do sucesso que alcançou, a ciência do Direito de Kelsen năo teria "resistido às provas do tempo nem às dos fatos" (ROULAND, 2008, p. 404). A antropologia poderia, entăo, contribuir para uma abordagem intercultural e pluralista do direito, na construçấo de um direito que responda melhor aos problemas da pós-modernidade, para evitar que tanto o sistema da modernidade, quanto o sistema da tradiçấo vá longe demais: as sociedades 
tradicionais podem aprender com as experiências das sociedades ocidentais e com as conquistas da modernidade, assim como a experiência das sociedades tradicionais é indispensável para nossa sociedade ocidental. A antropologia poderia demonstrar "como a uniformidade pode destruir a unidade, e os meios de paliar seus excessos" (ROULAND, 2008, p. 406).

A partir da leitura acima exposta quanto às contribuiçōes da Antropologia Jurídica para o estudo do Direito, a proposta do presente trabalho é esboçar as contribuiçôes do relativismo antropológico e "anti anti-relativismo" do antropólogo norte-americano Clifford Geertz para a compreensăo do fenômeno jurídico.

\section{ETNOCENTRISMO E RELATIVISMO: A QUESTÃO DA DIVERSIDADE CULTURAL}

O etnocentrismo é a visăo que considera a sua cultura como melhor e superior às demais culturas, vistas como selvagens e inferiores. Um fenômeno que mistura elementos intelectuais, mas também emocionais (cf. ROCHA, 1994). Em geral, o etnocentrismo se caracteriza por uma postura que diferencia o civilizado e o selvagem. Náo pode ser tido propriamente como a cultura de uma época, pois caracteriza o choque cultural - sempre possível - quando alguém se defronta com uma cultura totalmente diferente da sua. Trata-se de uma postura de imediata rejeiçâo e aversâo ao outro, como explica Claude Levi-Strauss:

"Hábitos de selvagem", "na minha terra é diferente", "năo se deveria permitir isso",
etc., tantas reaçóes grosseiras que traduzem esse mesmo calafrio, essa mesma
repulsa, diante de maneiras de viver, de crer ou de pensar que nos săo estranhas.
Assim, a Antiguidade confundia tudo que năo participava da cultura grega (depois
greco-romana) sob a mesma denominaçáo de bárbaro; a civilizaçáo ocidental
utilizou em seguida o termo de selvagem com o mesmo sentido. (LEVI-STRAUSS,
1976, p. 333)

Como explica Levi-Strauss (1976), essa atitude rejeita a evidente diversidade cultural humana. Diversidade que se caracteriza e se configura năo somente pelo isolamento das culturas - o que é muito raro, segundo Levi-Strauss (1976, p. 333), dando-se somente excepcionalmente e por curtos períodos - mas principalmente pelos encontros de culturas e pela necessidade de se diferenciarem dos demais grupos e de serem si próprios. Por isso, essa diversidade é, na verdade, menos em funçăo do afastamento dos grupos humanos e mais de suas relaçōes.

Mas por que, diante da evidente diversidade de culturas, adotamos a postura grosseira do etnocentrismo? Segundo Levi-Strauss (1976, p. 334) a atitude baseia-se em fundamentos psicológicos sólidos, de modo que tende a reaparecer quando estamos diante de uma situaçăo inesperada.

O paradoxo do etnocentrismo é que rejeitar o outro como selvagem é o que caracteriza o selvagem de forma mais particular:

Esta atitude de pensamento, em nome da qual os "selvagens" (ou todos aqueles que se convencionou considerar como tais) săo excluídos da humanidade, é justamente a atitude mais marcante e distintiva destes próprios selvagens. Com efeito, sabe-se 
que a noçăo de humanidade, englobando, sem distinçăo de raça ou civilizaçăo, todas as formas da espécie humana é muito recente e de expansăo limitada. Mesmo onde ela parece ter atingido seu desenvolvimento mais elevado, náo é certo, de modo algum - como a história o mostra - que năo esteja sujeita a equívocos ou regressóes. (LEVI-STRAUSS, 1976, p. 334)

Assim, Levi-Strauss (1976, p. 334) nos ensina que o etnocentrismo é muito comum, pois, para vastas fraçóes de povos ao longo de muitos anos, a ideia de uma humanidade una năo existia. Tanto que era comum muitas tribos se autodesignarem como "seres humanos" ("bons", "perfeitos") enquanto os outros (que năo partilhavam as mesmas virtudes e humanidade) eram tidos como maus. Aí está seu paradoxo: ao ter o outro como bárbaro está-se tomando emprestada uma atitude típica daqueles que se tem como bárbaros: "O bárbaro é inicialmente o homem que acredita na barbárie." (LEVISTRAUSS, 1976, p. 335).

Aqui se encontra também o paradoxo dos direitos humanos: afirma-se uma humanidade única, no entanto, essa afirmaçăo parece contradizer a observaçấo comum de que há uma enorme diversidade cultural. Esse paradoxo é a força e a fraqueza das declaraçōes de direitos dos homens:

As grandes declaraçóes dos direitos do homem têm também elas esta força e esta fraqueza: enuncia um ideal que raramente atenta para o fato de que o homem náo realiza sua natureza numa humanidade abstrata, mas em culturas tradicionais, cujas mudanças as mais revolucionárias deixam subsistir aspectos intactos e se explicam a si mesmas em funçáo de uma situaçáo estritamente definida no tempo e no espaço. Colocado entre a dupla tentaçáo de condenar experiências que o ferem afetivamente e de negar diferenças que năo compreende intelectualmente, o homem moderno entregou-se a centenas de especulaçôes filosóficas e sociológicas, para chegar a acordos inúteis entre pólos contraditórios e explicar a diversidade das culturas procurando suprimir o que ela tem de escandaloso e chocante. (LEVISTRAUSS, 1976, p. 335)

Liga-se ao etnocentrismo, ainda, o evolucionismo social:

Mais precisamente, trata-se de uma tentativa de suprimir a diversidade das culturas fingindo reconhece-las plenamente. Pois ao tratar os diferentes estados em que se encontram as sociedades humanas, tanto antigas quanto longínquas, como estágios ou etapas de um desenvolvimento único que, partindo do mesmo ponto, deve fazê-los convergir para a mesma meta, vê-se bem que a diversidade é apenas aparente. A humanidade se torna única e idêntica a si mesma; só que esta unidade e identidade se podem realizar progressivamente, e a variedade das culturas ilustra os momentos de um processo que dissimula uma realidade mais profunda ou atrasa sua manifestaçăo. (LEVI-STRAUSS, 1976, p. 336)

O evolucionismo social diferencia-se claramente do evolucionismo biológico, podendo ser considerado um falso evolucionismo. $\mathrm{O}$ evolucionismo biológico nasceu como uma hipótese de trabalho de Charles Darwin, pautada em observaçōes e com um espaço pequeno para interpretaçôes. Os fósseis e as gradativas alteraçóes biológicas dos organismos permitiram ao naturalista corroborar a hipótese da evoluçáo das espécies. De maneira distinta, quando se trata de uma evoluçấo das culturas é muito mais difícil testar qualquer hipótese, em especial porque os diferentes modos, por exemplo, de se talhar uma peça como um machado (LEVI-STRAUSS, 1976, p. 335) nâo dăo origem 
a outra peça, assim também năo há como afirmar com alto grau de probabilidade uma cadeia evolutiva de instituiçôes, crenças ou desejos.

Além disso, o evolucionismo social é anterior ao biológico: pode-se encontrar já nas afirmaçóes de Pascal que comparava a humanidade a um ser biológico, tendo sido mais desenvolvido posteriormente por Herbert Spencer (mais ligado ao evolucionismo social) e Edward Tylor (um dos principais nomes do evolucionismo cultural, juntamente com Lewis Morgan e James Frazer). Como explica Levi-Strauss (1976, p. 337), o evolucionismo social năo se trata de uma teoria científica, mas de uma falsa maquiagem para o problema filosófico da diversidade das culturas humanas diante da unidade da humanidade.

Como contraponto ao etnocentrismo e ao evolucionismo cultural, desenvolveu-se no âmbito da antropologia o relativismo cultural. Foi com Franz Boas no final do século XIX que essa perspectiva começou a se desenvolver de maneira marcante: "foi ele o primeiro a perceber a importância de estudar as culturas humanas nos seus particulares" (ROCHA, 1994, p. 40). Boas se contrapôs a entăo dominante perspectiva evolucionista nos estudos antropológicos e "desenvolveu o particularismo histórico (ou a chamada Escola Cultural Americana), segundo a qual cada cultura segue os seus próprios caminhos em funçâo dos diferentes eventos históricos que enfrentou" (LARAIA, 2001, p. 39). ${ }^{4}$

Para Rapchan, adotar a perspectiva relativista simultaneamente à realizaçâo do trabalho de campo, a partir do final do século XIX, significou "a abertura das possibilidades que desembocaram lenta, mas eficazmente, na produçấo de um tipo de conhecimento dedicado a registrar e refletir sobre o humano, em que pesam todas as tendências localistas e universalistas voltadas a pensar as culturas" (RAPCHAN, 2002, p. 261). De acordo com Rapchan, o relativismo é hoje condiçấo sine qua non para o desenvolvimento da antropologia. Independentemente da tendência, escola ou corrente que se observe, implica, assim, que a antropologia se paute na "recusa ao julgamento das culturas humanas a partir de parâmetros morais, estéticos, políticos ou quaisquer outros, referências que fundamentam cânones externos ao grupo em questăo" (RAPCHAN, 2002, p. 261).

Relativizar é o eterno exercício de transformar o familiar em exótico e o exótico em familiar (DAMATTA, 1987, p. 14).

\section{0 ANTI ANTI-RELATIVISMO DE CLIFFORD GEERTZ}

A adoçấo da perspectiva relativista na antropologia tem uma importância central para esse campo de estudos: trata-se, hoje, de sua característica central. Mas essa

4 Antes ainda das obras de Franz Boas alguns autores demonstravam posturas relativistas em seus escritos antropológicos. E o caso, por exemplo, de Michel de Montaigne que, no ensaio "Os canibais" expôe sua visâo sobre a sociedade indígena face à europeia dizendo que náo vê: "nada de bárbaro ou selvagem no que dizem daqueles povos [indígenas]; na verdade, cada qual considera bárbaro o que nâo se prática em sua terra". Sobre os ritos antropofágicos afirma: "Năo me parece excessivo julgar bárbaros tais atos de crueldade, mas que o fato de condenar tais defeitos náo nos leve à cegueira acerca dos nossos. Estimo que é mais bárbaro comer um homem vivo do que o comer depois de morto; e é pior esquartejar um homem entre suplícios e tormentos e o queimar aos poucos, ou entregá-lo a cáes e porcos, a pretexto de devoçăo e fé, como náo somente o lemos mas vimos ocorrer entre vizinhos nossos conterrâneos." (Montaigne apud SANTOS, 2008, p. 42). 
perspectiva seria uma postura prévia adotada pelos antropólogos ou estaria implícita no campo antropológico?

Para o fundador da antropologia interpretativa, o antropólogo norte-americano Clifford Geertz, o relativismo estaria implícito no campo: "talvez particularmente na antropologia cultural, mas também em boa parte da arqueologia, da linguística antropológica e da antropologia física" (GEERTZ, 2001, p. 49). De acordo com Geertz:

Năo foi a teoria antropológica como tal que fez nosso campo de investigaçăo parecer um argumento poderoso contra o absolutismo no pensamento, na moral e no juízo estético, mas sim os dados antropológicos: costumes, crânios, vestígios arqueológicos e léxicos. A ideia de que foram Boas, Benedict e Melville Herskovits, com a ajuda européia de Westermarck, que infectaram o nosso campo com o vírus relativista, e de que Kroeber, Kluckhohn e Redfield, com ajuda similar de Lévi-Strauss, lutaram para nos livrar dele, năo passa de mais um mito a confundir toda essa discussấo. Afinal, Montaigne pôde tirar conclusōes relativistas, ou de aparência relativista, de ter ouvido falar que os caraíbas năo usavam calças; năo precisou ler Patterns of Culture. Mesmo antes disso, contemplando "certos indígenas da raça chamada calaciana", entre os quais dizia-se que os homens comiam os próprios pais, Heródoto chegou, como seria de se esperar, a visóes semelhantes. (GEERTZ, 2001, p. 49)

Esse trecho foi retirado do livro Nova Luz sobre a Antropologia, uma coletânea de ensaios do antropólogo norte-americano, com textos autobiográficos, ensaios que discutem "angústias morais" surgidas do trabalho de campo, questóes epistemológicas e políticas. 0 capítulo 3, que é dedicado à discussăo sobre o relativismo, recebeu título intrigante, de acordo com a verve do autor: "Anti anti-relativismo".

Geertz explica que o objetivo do texto é destruir o medo do relativismo cultural. Mas atacar o anti-relativismo é diferente de defender a visăo relativista. $O$ estilo do título através-do-espelho sugere que a dupla negativa objetiva rejeitar algo (o anti-relativismo) sem que com isso se comprometa com o que este algo rejeita - ou seja, rejeita o anti-relativismo, mas sem adotar o relativismo.

Nessa empreitada "anti anti-relativista", o norte-americano explica que a maioria dos conceitos de "relativismo" foi formulada por seus adversários que o pintaram de forma absoluta. Para seus inimigos, o relativismo conduziria ao niilismo, subjetivismo, incoerência, maquiavelismo, estupidez ética, cegueira estética. Como exemplo, Geertz cita Paul Johnson que no livro Modern Times, em que descreve a história do mundo depois de 1917 aponta o relativismo como o grande mal do século XX:

[...] começando por um capítulo intitulado 'Um mundo relativista' [...], descreve todo o desastre moderno - Lenin, Hitler, Amin Bokassa, Sukarno, Mao, Nasser e Hammarskjöld, o estruturalismo, o New Deal, o holocausto, as duas guerras mundiais, 1968, a inflaçăo, o militarismo xintoísta, a OPEP e a independência da Índia - como resultado de uma coisa chamada 'a heresia relativista'. 'Um grande trio de inventivos sábios alemáes' - Nietzsche, Marx e (com a poderosa ajuda de Frazer - nossa contribuiçăo) Freud - destruiu moralmente o século XIX, assim como Einstein, ao acabar com o movimento absoluto, destruiu-o cognitivamente, e Joyce, ao abolir a narrativa absoluta, destruiu-o esteticamente (GEERTZ, 2001, p. 52-53).

Porém, Geertz duvida que o relativismo, entendido como excessiva sensibilidade aos elementos de outras culturas, conduza ao niilismo, à falta de opiniăo sobre o que é bom ou mal, verdadeiro ou falso: 
A imagem de um vasto número de leitores de antropologia vagando por aí com uma mentalidade tăo cosmopolita a ponto de náo terem opiniáo sobre o que é ou năo verdadeiro, bom ou belo, parece-me sobretudo uma fantasia. Pode haver alguns niilistas autênticos por aí, na Rodeo Drive de Bervely Hills ou em Times Square, mas duvido que muitos se tenham tornado niilistas por excessiva sensibilidade aos apelos de outras culturas; e pelo menos a maioria das pessoas que eu encontro, leio ou sobre quem leio, assim como eu mesmo, está totalmente comprometida com uma coisa ou outra, em geral provinciana. "É o olhar da infância que teme os demônios de brinquedo": o anti-relativismo, em boa parte engendrou a angústia de que se alimenta. (GEERTZ, 2001, p. 51)

Partindo da percepçăo de que posiçóes relativistas estăo no cerne da herança antropológica, Geertz defende: o que parece um debate sobre as implicaçóes mais amplas da antropologia é, na verdade, um debate sobre como conviver com elas. O relativismo e o anti-relativismo devem fornecem respostas genéricas à maneira como nossa percepçáo das coisas é afetada pelo impulso centrífugo da antropologia - lugares distantes, épocas distantes, espécies distantes... gramáticas diferentes. O relativismo serve, assim, para afugentar certos modos de pensar e nos encaminhar para outros, năo para gerar mentes niilistas.

Foram várias as tentativas de aplacar o relativismo (entre elas o materialismo harrisoniano e o evolucionismo popperiano). Geertz concentra-se, em sua empreitada teórica, basicamente em duas: a) a perspectiva naturalista, que buscou, em termos gerais, restaurar um conceito de "Natureza Humana" independente do contexto5; e b) a perspectiva racionalista que buscou reinstituir o conceito de "Mente Humana" também independente do contexto ${ }^{6}$.

Geertz faz uma ressalva de que a discussâo que ele quer fomentar năo está a insinuar que os seres humanos náo seriam seres biológicos com características intrínsecas:

Os homens năo podem voar e os pombos náo podem falar. Nem se trata de saber se eles exibem atributos comuns de funcionamento mental onde quer que os encontremos. Os papuanos invejam, os aborígenes sonham. A questăo é como devemos entender esses fatos indiscutíveis ao explicarmos rituais, analisarmos ecossistemas, interpretarmos sequências fósseis ou compararmos línguas. (GEERTZ, 2001, p. 54)

Geertz também náo está questionando a validade das ciências que aponta como naturalistas ou racionalistas, mas está preocupado com as posiçóes que essas pesquisas têm fomentado: "săo os machados que, com uma determinaçăo crescente, quase evangélica, estâo sendo ativamente afiados com a ajuda delas" (GEERTZ, 2001, p. 55).

Dentro da perspectiva naturalista, por exemplo, a obra de Mary Midgley, Beast Man, The Roots of Human Nature, trata da natureza humana e do problema do mal, destacando que os males sâo reais e năo uma fantasia criada pela cultura. Haveria, assim, uma estrutura adjacente à natureza humana que a cultura completaria e exprimiria.

5 Geertz se refere a sociobiologia, psicologia evolucionista e outras orientaçôes hiperadaptativas, mas também a perspectivas derivadas da psicanálise, da ecologia, da neurologia, da etologia do imprinting, de certos tipos de teoria do desenvolvimento e de algumas correntes do marxismo.

6 Trata-se do neo-intelectualismo associado ao estruturalismo e outras orientaçóes hiperlogicistas; linguística gerativa, psicologia experimental, pesquisa sobre inteligência artificial, microssociologia do estratagema e contra-estratagema e certos tipos de teoria do desenvolvimento derivadas do marxismo. 
A autora se apoia na zoologia, em estudos sobre a natureza de outras espécies para sustentar seus argumentos. Diante dessa teorizaçáo, Geertz questiona: que fatos seráo antinaturais e quais abominaçôes serăo impositivas?

Midgley responde afirmando que haveria um sentido fraco e um sentido forte para os conceitos. Assim, no sentido fraco, o sadismo seria natural (o que significa que existe e deve ser reconhecido - há impulsos naturais), mas num sentido forte seria antinatural (uma política baseada no sadismo, por exemplo, e imposta às pessoas seria contrária à constituiçăo da natureza humana). Geertz chama essa resposta de "malabarismo conceitual", por meio do qual:

[...] (o natural pode ser antinatural quando pensamos na natureza "em seu sentido pleno") revela a tese básica de todos esses argumentos fundamentados na Natureza Humana: a virtude (cognitiva, estética, moral, tanto faz) está para o vício assim como a adequaçáo está para a desordem, a normalidade para a anormalidade, o bem-estar para a doença. A tarefa do homem, como a dos pulmóes ou da tireoide, é funcionar direito. Evitar os incapacitados pode ser perigoso para a saúde. (GEERTZ, 2001, p. 57)

Com esse tipo de teoria, passa-se a afirmar a existência de um "desvio", que é sempre desvio de um determinado padrăo. ${ }^{7}$ Assim, o medo do relativismo levou a uma concepçăo de natureza humana em que a diversidade cultural corresponde a uma série de expressóes, algumas sadias e outras năo, de uma realidade subjacente estável (natureza essencial do homem) e caberia à antropologia discernir a substância dessa realidade. Năo se pode perder de vista que esse conceito se amolda a praticamente qualquer forma, a qualquer ideologia que apareça. Com sua verve habitual, Geertz (2001, p. 61) ironiza: "uma das características centrais da Natureza Humana', teria dito um gênio anônimo 'é um judiciário autônomo"'.

Por sua vez, a perspectiva racionalista apresenta, segundo Geertz (2001), semelhanças com a naturalista, em sua tendência a ver a diversidade como superficial e a universalidade como profunda. Representa interpretaçóes pessoais como qualidades essenciais impostas pelos objetos ao pensamento e nâo como construçóes mentais impostas ao objeto.

Entretanto, há divergências. Enquanto o naturalismo visualiza o relativismo moral como a causa dos males da humanidade, o racionalismo vê o relativismo conceitual como essa causa; o naturalismo enfatiza o desvio (foca nos desvios de conduta), enquanto racionalismo traz de volta a concepçăo de "pensamento primitivo" (dá ênfase aos enigmas da crença). Haveria, de acordo com Geertz, uma gama de teorias racionalistas que se posicionam contra o relativismo, elas teriam em comum "uma visăo fundacionista da Mente". Geertz dá relevo a uma coletânea anti-relativista organizada por Martin Hollis e Steven Lukes: Rationality and Relativism. Entre os autores da coletânea há três antropólogos da coletânea: Ernest Gellner, Robin Horton e Dan Sperber.

7 Nesse sentido, é bastante demonstrativo o trabalho de Robert Edgerton (no livro Estudo do desvio: homem marginal ou homem comum?) que conclui ser necessário para tornar produtiva a pesquisa em antropologia uma concepçáo de natureza humana universal. Sobre o texto de Edgerton, afirma Geertz: "O 'instinto' de autopreservaçáo do homem, seu mecanismo de luta e fuga e sua intolerância ao tédio sáo usados como exemplos [da natureza humana universal]; e, num argumento que eu minha inocência eu supunha haver desaparecido da antropologia, junto com o evemerismo e a promiscuidade primitiva, sugere-se que, se tudo correr bem com a ciência, poderemos, com o tempo, ser capazes de julgar náo apensar indivíduos mas sociedades inteiras como desviantes, falhas e antinaturais" (GEERTZ, 2001, p. 60). 
Gellner ressalta, ao criticar o relativismo, que o fato de outras pessoas náo acreditarem em nossa explicaçâo para a formaçáo da realidade năo prova que nâo seja a única correta. Horton, por sua vez, defende um núcleo cognitivo comum, uma teoria principal do mundo, culturalmente universal, que sofreria apenas variaçōes banais. Mas é Sperber que desfere o ataque mais radical. Para ele, o relativismo năo é uma posiçăo defensável porque năo tem ideias, mas meias ideiais, semicrenças. O relativismo implicaria em representaçôes mal formuladas de quando se busca processar mais informaçóes do que permite nossa capacidade conceitual intrínseca.

Sobre essas posiçôes, conclui Geertz: "a ressurreiçâo da Mente Humana como ponto imóvel do mundo em rotaçáo desfaz a ameaça do relativismo cultural ao desarmar a força da diversidade cultural. Como acontece com a 'Natureza Humana', a desconstruçáo da alteridade é o preço da verdade" (GEERTZ, 2001, p. 65). No entanto, essa verdade năo vale seu preço.

Cabe à antropologia, afirma Geertz, examinar dragôes, năo os domesticar ou abominá-los. Importa manter o mundo em desequilíbrio, puxando tapetes - tranquilizar é tarefa de outros, a tarefa da antropologia é inquietar:

Nesse movimento de distanciamento de antigos triunfos transformados em comodismo, de grandes avanços de outrora transformados em barreiras, a antropologia desempenhou em nossa época um papel de vanguarda. Fomos os primeiros a insistir numa série de coisas: que o mundo náo se divide entre devotos e supersticiosos; que há esculturas nas selvas e pinturas nos desertos; que a ordem política é possível sem o poder centralizado, e a justiça, proba sem regras codificadas; que as normas da razăo năo foram estabelecidas na Grécia nem a evoluçấo da moral se consumou na Inglaterra. Mais importante, fomos os primeiros a insistir em que vemos a vida dos outros através das lentes que nós próprios polimos e que os outros nos vêem através das deles. Náo é de surpreender que isso tenha levado alguns a pensar que o céu estava desabando, que o solipsismo se apoderara de nós e que o intelecto, o juízo e até a simples possibilidade de comunicaçăo haviam desaparecido. A redefiniçăo de horizontes e a descentralizaçăo de perspectivas já tiveram esse efeito antes.

Nesse sentido, a objeçăo de Geertz ao anti-relativismo se dá nâo por este rejeitar a ideia de que "tudo depende de como você vê as coisas" ou uma abordagem local da moral, mas pelo fato de imaginar que tais abordagens só podem ser derrotadas se a moral for posta acima da cultura e o conhecimento acima de ambas.

Cabe valorizar e reconhecer a cultura. Assim, a contribuiçăo da antropologia é justamente fazer com que os juristas se atentem para a alteridade, para o reconhecimento do outro em seu mundo, para a efemeridade, para as mudanças culturais, para a falta de harmonia e para a ausência de solidez.

\section{A CONTRIBUIÇÃO DE GEERTZ PARA SE REFLETIR SOBRE O DIREITO}

A antropologia pode contribuir de forma muito significativa para que os juristas lancem novos olhares para a sociedade, em especial, para a diversidade cultural.

Primeiramente, o estudo de antropologia pode auxiliar na desconstruçấo do "senso 
comum teórico dos juristas" (para se utilizar uma expressăo de Luis Alberto Warat, 1982) que tendem a visualizar a história a partir de uma perspectiva evolucionista. 0 evolucionismo se encontra nos manuais jurídicos e se manifesta de maneira especial nos primeiros capítulos dos Trabalhos de Conclusáo de Curso ${ }^{8}$ apresentados pelos estudantes de Direito - em geral, o primeiro capítulo é dedicado à história do instituto estudado pelo aluno, fazendo-se uma digressấo que remonta aos gregos e romanos e chega até o presente de forma linear e progressiva. Assim, os juristas tendem a ver os institutos jurídicos atualmente em vigor como o resultado de uma evoluçâo e de um progresso contínuo, com isso, olham para as culturas que possuem institutos jurídicos diferentes como culturas atrasadas, que ainda náo chegaram a mesma etapa da evoluçăo histórica em que se encontram. Essa percepçăo simplista calcada na ideologia do progresso pode ser repensada a partir do olhar relativista da antropologia, em que os juristas irâo perceber que nâo é simples se traçar a relaçăo cultural entre os institutos do Direito civil brasileiro e aqueles de um emergente direito civil romano, por exemplo. Nessa trajetória (de Roma até o Brasil) há inúmeras mudanças, novas criaçôes, retrocessos, disputas políticas e avanços que dificilmente permitem olhar para o direito romano como antepassado evolutivo do direito brasileiro.

Nâo se trata, no entanto, de negar totalmente o progresso e os eventuais avanços da humanidade, mas de olhá-lo com muita prudência e com especial cuidado para náo se escalonar culturas, contextos históricos e políticos totalmente diferentes na mesma tabela progressiva. Sobre o progresso, a advertência de Levi-Strauss revela essa prudência:

[...] o "progresso" (se é que esse termo convém para designar uma realidade bem diferente daquela à qual nos dedicaramos inicialmente) năo é nem necessário, nem contínuo; procede por saltos, pulos, ou, como diriam os biólogos, por mutaçôes. Esses saltos e pulos náo consistem em ir sempre além na mesma direçăo; acompanhavamse de mudanças de orientaçáo, um pouco à moda do cavalo do xadrez, que tem sempre diversas progressôes à sua disposiçâo, mas nunca no mesmo sentido. A humanidade em progresso em nada se parece com um personagem subindo uma escada, acrescentando por cada um de seus movimentos um novo degrau a todos os outros que já tivesse conquistado; evoca antes o jogador cuja chance está dividida em muitos dados e que, cada vez que os lança, os vê se espalharem no pano ocasionando contas bem diferentes. $O$ que se ganha num lance se arrisca a perder no outro, e é apensar de um tempo a outro que a história é cumulativa, isto é, que as contas se somam para formar uma combinaçăo favorável. (LEVI-STRAUSS, 1976, p. 342-343).

Por sua vez, o debate de Geertz sobre o anti-relativismo também permite lançar uma reflexăo sobre o Direito. O Direito positivado já năo é capaz de resolver os problemas que se colocam num mundo que é cada vez mais complexo, heterogêneo e marcado pela rapidez das mudanças tecnológicas.

Os perigos do anti-relativismo, revelados por Geertz, permitem concluir, analogicamente, que um retorno a um direito rigoroso, estrito e natural năo é o melhor caminho. Como sugerem Pazello, Maso e Kobora (2011), a antropologia convida a visualizar o

8 Para uma crítica das abordagens históricas no primeiro capítulo dos TCC's da Graduaçăo em Direito vero texto de Luciano Oliveira (Nâo me fale do Código de Hamurabi) e do Grupo de Estudos em História da Cultura Jurídica, Grupo de Estudos IUS COMMUNE (Por que história no primeiro capítulo do TCC?). 
direito como um produto cultural e, justamente por isso, flexível, móvel, em constante movimento.

Ainda em consonância com Geertz, cabe observar que o relativismo năo implica, como sugerem seus críticos, em niilismo. Adotar a perspectiva relativista para observar e perceber as culturas (incluído o Direito) implica em reconhecer a pluralidade de possibilidades e, assim, reconhecer que mudanças também săo possíveis na cultura e no Direito. O relativismo náo implica a aceitaçâo cega de uma cultura ou de um determinado sistema jurídico, sob a simplista justificativa de que seria o sistema hegemonicamente aceito naquela sociedade. Nesse sentido, o antropólogo e jurista francês Norbert Rouland defende sua posiçâo ao comentar um caso de excisăo de uma filha de muçulmanos ocorrida em território francês, ou seja, sob a incidência da legislaçăo francesa:

[...] fica o ridículo de qualificar de 'violências voluntárias à criança' o ato que Fofana [máe da menina] deixou realizar. Pois ele é ligado a um contexto cultural totalmente diferente, que podemos recusar, mas năo nos dispensa, para apreciar sua responsabilidade penal, de situá-la consoante coerçóes culturais nas quais ela se exerceu. Delicado exame de pluralismo jurídico? Sim, mas aparentado com a liberdade de pensamento. Esta sempre é valorizada, pois fazem dela o sinônimo do direito de resistência à opressáo. Mas iludimo-nos esquecendo também que ela pode legitimar pensamentos e atos contrários aos nossos. É por isso que posso a um só tempo condenar Fofana e aderir ao que C. Castoriadis escreve sobre o juízo de valores: "A lapidaçâo dos adúlteros é inaceitável para nós, assim como a amputaçâo das máos dos ladrōes, a prática da infibulaçăo e da excisăo de meninas... Meu respeito pelas culturas náo pode abarcar isto, e surge um ponto de interrogaçáo na medida em que penso que há mesmo assim uma certa solidariedade entre isso e o resto. Aí, decerto em virtude de meus próprios valores, ou seja, valores que reconheço e que escolhi em minha própria cultura, acaba o simples respeito pela cultura do Outro, tento compreender, mas náo respeito no sentido que aceito". (ROULAND, 2008, p. 201)

Assim, para Rouland (2008) a questăo de relativizar para compreender o ato dentro do contexto cultural se mantém como uma postura típica da antropologia e que ele, enquanto antropólogo, realiza. No entanto, a partir de sua cultura e dos valores próprios que tem ele avalia como inaceitáveis certas condutas - nesse caso, deixa claro que está realizando um juízo de valores.

O efeito do relativismo é olhar para as várias culturas e buscar reconhecer o outro imerso em sua própria cultura para melhor compreendê-lo e, ainda, buscar visualizar quais contribuiçóes a cultura a partir da qual se fala (incluído o Direito) pode receber do outro. Relativizar é, nas palavras de Roberto DaMatta como um abraço destemido que damos quando "pretendemos entender honestamente o exótico, o distante e o diferente, o 'outro'." (DAMATTA, 1987, p. 11).

A visăo do anti-relativismo através do espelho, como propóe Geertz, contribui, ainda, com o debate sobre a universalidade dos direitos humanos. Viu-se com Levi-Strauss (1976) que o relativismo cultural aponta para o paradoxo dos direitos humanos: eles săo universais, mas se defrontam com culturas muito diferenciadas - a humanidade nâo se realiza na abstraçâo da universalidade, mas na concretude de cada cultura. 
Como bem enfatiza a antropóloga Rita Laura Segato, a defesa dos direitos humanos no Ocidente, ao náo observar as diferentes concepçôes de justiça e direitos que permeiam as diversas culturas, acabou, em alguns casos, por resultar em uma desmoralizaçăo da diferença. Trata-se do que María Cristina Álvarez Degregori denomina "alterofobia": com críticas das práticas alheias, gerou-se uma cegueira com relaçăo às violaçôes dos direitos humanos cometidas pelos países ocidentais (cf. SEGATO, 2006, p. 215).

Assim, a crítica de Geertz ao anti-naturalismo se assemelha à crítica de Segato, quando esta afirma que em um processo que deveria ser sempre de mâo dupla "e repatriar o olhar crítico constantemente dirigido aos outros, acaba-se produzindo acriticamente a equivocada certeza de superioridade moral e o nocivo reforço de estereótipos negativos, com consequências frequentemente nefastas e com o custo de vidas" (SEGATO, 2006, p. 215).

O anti anti-relativismo de Geertz pode contribuir justamente para que esse processo seja sempre de mâo dupla: que o olhar crítico dirigido ao outro também seja voltado à própria cultura.

Talvez esse novo olhar - novo porque adquire uma nova lente, a lente antropológica permita-nos reconhecer a necessidade de mudança: o direito deve ir além, ultrapassar seus engessados limites positivistas e jusnaturalistas para se reconhecer enquanto cultura.

Nesse sentido, um passo muito importante é trazer para o "jurídico" a contribuiçăo antropológica da "alteridade": visualizar o outro em seu mundo, em seu contexto, buscar perceber, como almeja Geertz (2011) para a antropologia, "quem as pessoas de determinada formaçấo cultural acham que sâo, o que elas fazem e por que razôes elas creem que fazem o que fazem".

É, portanto, crucial que aqueles que têm o poder de dizer o direito (especialmente os juízes), tenham contato com a antropologia, para que, antes de decidir, reflitam sobre a diversidade cultural. Diante de um processo judicial, cabe ao magistrado lembrar que a lente que lhe permite ver e entender determinado case é marcada pela sua cultura, assim como aqueles que săo partes na lide que se desenvolve diante dele também atuam e atuaram tendo em vista a sua própria cultura, que pode ser muito diferente daquela do magistrado.

Assim, talvez a maior contribuiçăo da discussăo sobre o relativismo, nos termos propostos por Geertz, seja a de que a perspectiva antropológica relativista pode contribuir para aguçar a sensibilidade dos juristas e dos trabalhadores do Direito. A lei congrega um conjunto de normas, resultado de um intrincado complexo de relaçóes morais, políticas, religiosas, enfim, culturais. Mas nâo basta essa lei positivada para se compreender uma sociedade e uma cultura. Exige-se, hoje, muito mais daqueles a quem cabe o poder de dizer o direito. A antropologia pode contribuir justamente aguçando-lhes a sensibilidade, para que esse Direito que lhes cabe dizer esteja mais atento às especificidades e complexidades da condiçăo humana. 


\section{CONSIDERAÇÕES FINAIS}

Uma viagem pela antropologia e sua abordagem da diversidade cultural permite compreender os dilemas humanos a partir do conhecimento do homem sobre o homem, mas sem partir de quaisquer axiomas definitivos.

Assim, buscou-se encontrar na antropologia meios de se lançar novos olhares ao fenômeno jurídico que permitam reconhecê-lo como um fenômeno cultural, portanto, mutável e tăo diverso como a cultura.

Viu-se que o etnocentrismo é uma postura humana comum, que a própria antropologia, nos seus primórdios afirmou a superioridade e inferioridade de certas culturas de modo a unir a humanidade na busca de sua realizaçăo evolutiva. No entanto, o evolucionismo cultural, pautado na ideia de progresso, é algo que năo se sustenta empiricamente e representa muito mais uma resposta ideológica para o dilema da diversidade cultural (captada pela observaçâo) diante da afirmaçâo da unidade do humano.

Nesse sentido, a antropologia responde com o relativismo, a postura de tornar exótico o que é familiar e familiar o que é exótico. Trata-se de uma postura com a qual os juristas podem aprender a questionar seus próprios parâmetros culturais (inclusive o próprio direito) e buscar compreender melhor a cultura alheia. O relativismo também possibilita questionar o senso comum teórico dos juristas que se sustenta no evolucionismo social manifesto nos livros jurídicos e na defesa de uma história linear dos institutos jurídicos. Ora, o relativismo leva a questionar essa evoluçâo e compreender que há inúmeros avanços, retrocessos, rupturas e disputas que tornam os contextos mais complexos e nâo permitem defender uma evoluçăo linear dos institutos jurídicos.

Com o antropólogo norte-americano Clifford Geertz foi-se além do debate sobre o relativismo para abordar o anti anti-relativismo. $O$ anti-relativismo implica em medo de que o relativismo possa conduzir ao niilismo e ausência de parâmetros de avaliaçáo. Porém, explica Geertz que relativismo năo conduz a dificuldade em se distinguir o bom do mal, o belo do feio, mas tăo somente implica em maior sensibilidade às culturas alheias. O relativismo náo implica em aceitar certas formas de pensamento, mas sim em rejeitar algumas, como o etnocentrismo e o evolucionismo. 0 papel da antropologia năo é domesticar, mas inquietar as mentes.

Ao se projetar as reflexóes de Geertz para o Direito pudemos ver que a antropologia năo nos dá uma reposta simples para o paradoxo dos direitos humanos, ou seja, o fato de que os direitos humanos afirmam sua universalidade, mas a humanidade se realiza em suas particularidades, na cultura. $O$ que a antropologia nos permite é justamente visualizar esse paradoxo para o qual năo há resposta fácil.

A contribuiçăo do anti anti-relativismo de Geertz é evitar que a afirmaçăo da universalidade dos direitos humanos gere a alterofobia quando se criticam as práticas alheias, mas se esquece as violaçōes de direitos praticadas pela própria cultura. Esse anti anti-relativismo exige o constante olhar no espelho e dirigir o olhar crítico nâo somente para o outro, mas também para si. Com isso, os juristas têm muito a aprender. 


\section{REFERÊNCIAS}

BÔAS FILHO, Orlando Villas. A constituiçâo do campo de análise e pesquisa da antropologia jurídica. Prisma jurídico: revista de Filosofia e Teoria Geral do Direito da Faculdade de Direito da UNINOVE, Sáo Paulo, v. 6, p. 333-349, 2007.

DAMATTA, Roberto. Relativizando: uma introduçâo à antropologia social. Rio de Janeiro: Editora Rocco, 1987.

GEERTZ, Clifford. Nova Luz sobre a Antropologia. Rio de Janeiro: Jorge Zahar Ed., 2001.

GEERTZ, Clifford. A mitologia de um antropólogo. Entrevistador: Victor Aiello Tsu. Folha de Sâo Paulo, 18 fev. 2011. Caderno Mais. Disponível em: 〈http://www1.folha.uol. com.br/fsp/mais/fs1802200103.htm>. Acesso em: 01 mai. 2012.

IUS COMMUNE - Grupo de Estudos em História da Cultura Jurídica. Por que história no primeiro capítulo do TCC? Folha Acadêmica, Centro Acadêmico XI de Fevereiro, CCJ/UFSC, $n^{\circ}$ 6, 2013-2. Disponível em: <https://iuscommuneufsc.files.wordpress. com/2014/05/folha-vi-grupo-de-histc3b3ria-do-direito.pdf〉. Acesso em 18 fev. 2018.

LARAIA, Roque de Barros. Cultura: um conceito antropológico. Rio de Janeiro: Jorge Zahar Ed., 2001.

LÉVI-STRAUSS, Claude. Raça e História In: LÉVI-STRAUSS, Claude. Antropologia Estrutural II. Rio de Janeiro: Tempo Brasileiro, 1976, p. 328-366.

OLIVEIRA, Luciano. Nâo fale no Código de Hamurábi! A pesquisa sóciojurídica na pós-graduaçáo em direito. Anuário dos Cursos de PósGraduaçâo em Direito. v. 13, p. 299330, Recife: EdUFPE, 2003.

PAZELLO, Ricardo Prestes; MASO, Tchenna Fernandes; KOBORA, Igor Augusto Lopes. Entre antropologia e direito: perplexidades no ensino jurídico. Direito e práxis: revista do Programa de Pós-Graduaçâo em Direito da Universidade do Estado do Rio de Janeiro, Rio de Janeiro, RJ, v. 3, n. 2, p. 56-70, 2011.

RAPCHAN, Eliane Sebeika. Relativismo epistêmico, relativismo antropológico: reflexôes sobre a produçâo do pensamento no âmbito das contribuiçôes da antropologia. Acta Scientiarum: Human and Social Sciences, Maringá, PR, v. 24, n. 1, p. 261-270, 2002.

ROCHA, Everardo P. Guimarâes. O que é etnocentrismo. Săo Paulo: Brasiliense, 1994.

ROULAND, Norbert. Nos confins do direito: antropologia jurídica da modernidade. Sâo Paulo: Martins Fontes, 2008. 
SANTOS, Breno Machado dos. Jean de Léry: O Montaigne dos viajantes. Revista Eletrônica Cadernos de História: publicaçáo do corpo discente do Departamento de História da Universidade Federal de Ouro Preto, Mariana, MG, ano 3, v. 5, n. 1, abr. 2008.

SEGATO, Rita Laura. Antropologia e direitos humanos: alteridade e ética no movimento de expansăo dos direitos universais. Mana: Programa de Pós-Graduaçăo em Antropologia Social - PPGAS-Museu Nacional, da Universidade Federal do Rio de Janeiro - UFRJ, Rio de Janeiro, v. 12, n. 1, p. 207-236, abr. 2006.

WARAT, Luis Alberto. Saber crítico e senso comum teórico dos juristas. Seqüência: Estudos Jurídicos e Políticos, Florianópolis, p. 48-57, jan. 1982. Disponível em: <https:// periodicos.ufsc.br/index.php/sequencia/article/view/17121>. Acesso em: 18 fev. 2018. 